\title{
UPAYA PENINGKATAN PENGETAHUAN MANAJEMEN LAKTASI UNTUK IBU HAMIL DAN MENYUSUI MELALUI KEGIATAN PENGABDIAN MASYARAKAT DI POSYANDU CEMPAKA MERAH-JAKARTA PUSAT
}

\author{
Maya Genisa ${ }^{1}$, Irfan Syarief ${ }^{2}$ dan Nazwirman ${ }^{3}$ \\ ${ }^{1}$ Program Studi Magister Sains Biomedis, Universitas YARSI \\ ${ }^{2}$ Program Studi Kedokteran, Universitas YARSI \\ ${ }^{3}$ Program Magister Manajemen, Universitas YARSI \\ E-mail: maya.genisa@yarsi.ac.id
}

\begin{abstract}
ABSTRAK
Air susu ibu atau ASI merupakan nutrisi yang sangat diperlukan khususnya oleh anak balita untuk pertumbuhan dan perkembangan. Namun sayangnya kesadaran untuk memberikan ASI ini belum sepenuhnya ada pada diri ibu-ibu menyusui. Data dari Kemenkes RI di tahun 2017 mencatat hanya 35\%, angka ini dibawah rekomendasi World Health Organization (WHO) sebesar 50\%. Ada beberapa faktor yang mempengaruhi rendahnya pemberian ASI eksklusif diantaranya adalah kurangnya dukungan orang sekitar, kurangnya pengetahuan mengenai laktasi dan faktor phsycologis. Untuk upaya peningkatan kesadaran para ibu-ibu khususnya ibu hamil dan menyusui di lingkungan Posyandu Cempaka Merah, Cempaka Putih Jakarta Pusat telah di selenggarakan oleh Prodi Magister Sains Biomedis Universitas YARSI melalui kegiatan Pengabdian Kepada Masyarakat (PKM). Kegiatan ini diselenggarakan secara online dengan menghadirkan pembicara dari Rumah Sakit PMI Bogor. Sebanyak 15 partisipan telah bergabung dalam kegiatan ini. Kepada partisipan dilakukan pretest dan posttest untuk mengkuantifikasi signifikansi secara langsung terhadap peserta. Berdasarkan statistik analisis menunjukkan bahwa kegiatan ini telah meningkatkan pemahaman peserta mengenai pengetahuan ASI dengan nilai skor meningkat dari $45 \%$ ke $91.67 \%$, pengetahuan mengenai teknik menyusui naik dari $28.89 \%$ ke $97.78 \%$ sedangkan pemahaman peserta mengenai phsycology menyusui juga meningkat dari $40 \%$ ke $93.33 \%$.
\end{abstract}

Kata Kunci: Laktasi, ASI, Penyuluhan, Posyandu, Ibu Hamil.

\section{PENDAHULUAN}

Kegiatan pengadian masyarakat dari universitas merupakan kegiatan yang sangat berguna untuk diaplikasikan pada kegiatan sehari-hari di masyarakat. Kegiatan ini tidak harus melibatkan teknologi tinggi tetapi dengan teknologi sedehana yang langsung bisa diaplikasikan di masyarakat dirasakan sangat berguna seperti contoh penangangan gambut yang bisa meningkatkan taraf ekonomi masyarakat (Kissinger dan Rina, 2020). Contoh yang lainnya dari kegiatan pkm adalah penerapan lampu penerangan jalan umum (pju) berbasis Solar Cell (Wahyu, 2019) begitu juga kegiatan lainnya yang berkaitan dengan kesehatan keluarga seperti penanganan laktasi adalah perlu 
bagi ibu hamil yang berpendiidkan rendah

Manajemen laktasi merupakan segala daya upaya yang dilakukan untuk membantu ibu mencapai keberhasilan dalam menyusui bayinya. Usaha ini dilakukan terhadap ibu dalam 3 tahap yaitu pada masa kehamilan (antenatal), sewaktu ibu dalam persalinan sampai keluar rumah sakit (perinatal), dan pada masa menyusui selanjutnya sampai anak berumur 2 tahun (postnatal) (Perinasia, 2007, p.1).

Perkembangan dan pertumbuhan bayi dan anak sangat dipengaruhi oleh ibu. Mulai dari masa kehamilan janin menerima nutrisi dari ibu melalui plasenta. Pada masa bayi didalam tubuh ibu secara alami telah disediakan makanan yang dibutuhkan untuk perkembangan dan pertumbuhan selanjutnya berupa ASI. Pada abad ke-19 beberapa studi kedokteran yang dilakukan di Eropa menunjukkan angka kematian dan kesakitan bayi-bayi yang diberikan ASI ternyata lebih rendah daripada yang diberi susu formula. Sehingga banyak ahli yang sepakat bahwa ASI lebih unggul daripada susu formula atau susu sapi.

Keberhasilan ASI eksklusif
sangat bergantung pada tahapan

manajemen laktasi, sehingga semua tahap harus dipersiapkan dengan baik supaya ASI eksklusif berjalan dengan sukses. Motivasi bidan, konseling dan perawatan payudara sangat mendukung upaya ini. Adapun ruang lingkup manajemen laktasi adalah periode postnatal, antara lain ASI eksklusif, teknik menyusui, memeras ASI, memberikan ASI peras, menyimpan ASI peras, pemenuhan gizi selama periode menyusui (Maryunani, 2012).

Pentingnya ASI Eksklusif tersebut melatarbelakangi pemerintah dalam menetapkan kebijakan berupa Kepmenkes

RI no.450/MENKES/IV/2004 tentang pemberian ASI secara eksklusif pada bayi Indonesia. Dalam kebijakan ini disebutkan bahwa Air Susu Ibu (ASI) secara eksklusif bagi bayi di Indonesia sejak bayi lahir sampai bayi berumur 6 (enam) bulan dan dianjurkan untuk dilanjutkan sampai anak berusia 2 (dua) tahun dengan pemberian makanan tambahan yang sesuai (Siregar, 2007, p.1). Sayangnya, di Indonesia angka pemberian ASI eksklusif masih tergolong rendah. Data dari Kemenkes RI di tahun 2017 mencatat hanya 35\%, angka ini dibawah rekomendasi WHO sebesar 50\%. Ada 
beberapa faktor yang mempengaruhi rendahnya pemberian ASI eksklusif diantaranya adalah kurangnya dukungan orang sekitar, kurangnya pengetahuan mengenai laktasi dan factor phsycologis.

Berdasarkan data tahun 2019 di Posyandu Cempaka Merah yang terletak di kelurahan Sumur Batu, Cempaka Putih, Jakarta Pusat jumlah ibu hamil dan menyusui sangat besar yaitu 60 orang ibu menyusui dan 4 orang orang ibu hamil. Adanya pandemi Covid-19 ini menyebabkan pemberian penyuluhan dilakukan secara daring melalui zoom meeting. Mengingat begitu pentingnya pemahaman manajemen laktasi untuk ibu-ibu hamil dan menyusui, maka peneliti tetap mengadakan kegiatan penyuluhan ini walaupun masih masa pandemi melalui kegiatan penyuluhan secara daring di Posyandu Cempaka Merah ini.

\section{PERUMUSAN MASALAH}

Berdasarkan latar belakang di atas, maka dapat dirumuskan beberapa masalah yang perlu diangkat melalui kegiatan PKM ini. Adapun permasalahan tersebut termasuk "mengetahui seberapa dalam pemahaman ibu-ibu di Posyandu Cempaka Merah mengenai manajemen laktasi serta bagaimana meningkatkan pemahaman ibu-ibu di Posyandu Cempaka Merah mengenai manajemen laktasi”.

\section{KHALAYAK SASARAN}

Peserta dari penyuluhan ini adalah ibu hamil dan ibu menyusui di lingkungan Posyandu Cempaka Merah, Jakarta Pusat.

\section{METODE KEGIATAN}

Kegiatan PKM di Posyandu Cempaka merah dilakukan dengan tujuan utama memberikan pemahaman manajemen laktasi terhadap ibu-ibu yang meliputi beberapa aspek seperti teknik pembersihan alat, teknik pemerasan, teknik penyimpanan dan teknik pemberian ASI itu sendiri terhadap bayi seperti ditunjukkan pada Gambar 1.

Adapun metode kegiatan penyuluhan yang dilakukan adalah dengan menghadirkan seorang Bidan dari Rumah sakit PMI Bogor yang secara langsung memberikan penyuluhan dan memperagakan bagaimana melakukan tindakan-tindakan tersebut. 


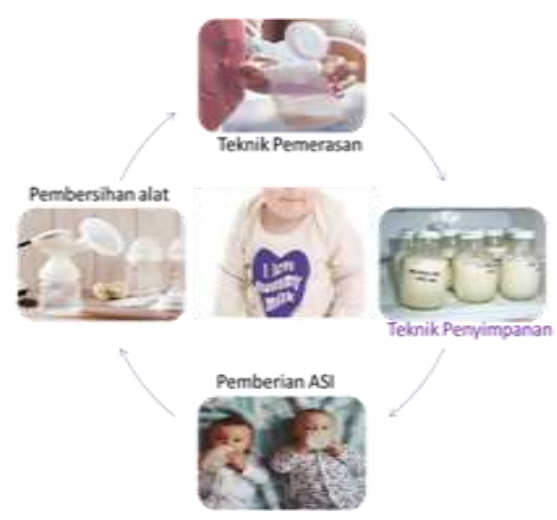

Gambar 1. Kegiatan manajemen laktasi

Kepada peserta, pembicara menjelaskan hal-hal sebagai berikut:

\section{Pembersihan Alat}

Metode pembersihan alat untuk penanganan ASI dijelaskan sebagai berikut:

- Pertama-tama memberikan penjelasan tentang cara membasuh tangan dengan benar

- Cara membersihkan bagian luar pompa ASI dengan tisu basah anti bakteri.

- Siapkan baskom yang berisi air hangat dan sabun untuk meletakkan semua bagian pompa $\underline{\text { ASI. }}$

- Hindari meletakkan bagian botol di wastafel karena dapat meningkatkan risiko botol terkontaminasi kuman.

- Menyikat dan membersihkan tiap bagian pompa dengan sikat khusus yang hanya digunakan untuk membersihkan perlengkapan bayi.

- Bilas semua bagian pompa ASI dengan air hangat selama kurang lebih 10-15 detik.

- Keringkan pompa ASI dengan tisu, handuk, atau lap yang masih baru dan belum digunakan.

\section{Teknik Penyimpanan}

Secara garis besar teknik penyimpanan dijelaskan sebagai berikut:

- ASI yang dipompa disimpan dalam botol-botol susu yang biasa digunakan.

- Segera memasukkan botol-botol susu tersebut kedalam kulkas ataupun.

\section{Pemberian ASI}

Acuan pemberian ASI dijelaskan sebagai berikut:

- Pastikan susu yang diberikan dalam keadaan hangat.

- Pastikan posisi bayi duduk tegak dan perlahan rendahkan punggungnya ketika aliran ASI bergerak dari botol.

- Pegang badannya mendekat ke tubuh Anda. 
- Ganti lengan tiap kali bayi disusui. Ini membantu memastikan perkembangan otak dan mata bayi.

- Beri jeda menghisap sebelum lanjut menyusui.

- Ikuti petunjuk bayi apakah ia sudah kenyang atau belum.

\section{HASIL DAN PEMBAHASAN}

\section{Hasil kuisioner dari peserta kegiatan}

Kegiatan ini dilakukan ketika sedang merebaknya pandemi COVID sehingga dikeluarkannya aturan dari pihak kampus untuk melaksanakan semua kegiatan secara daring tak terkecuali kegiatan PKM. Kegiatan ini dilakukan dalam bentuk penyuluhan dan demo secara daring dengan menggunakan ZOOM. Untuk melihat beberapa latar belakang dan informasi mengenai peserta, sebelum penyuluhan diberikan maka peserta diminta untuk mengisi kuisioner yang sudah disiapkan. Sebanyak 15 orang ibu hamil dan ibu menyusui sudah ikut berpartisipasi dalam kegiatan ini. Adapun latar belakang peserta adalah sebagai berikut

\section{Usia peserta}

Peserta yang hadir didominasi oleh ibuibu pada usia produktif yaitu sebanyak 47\% pada usia 25-34 tahun diikuti oleh 40\% pada usia dibawah 25 tahun dan 13 $\%$ pada usia 35-50 tahun. Adapun untuk detailnya dapat dilihat pada diagram yang ditunjukkan pada Gambar 2.

\section{Umur Peserta}

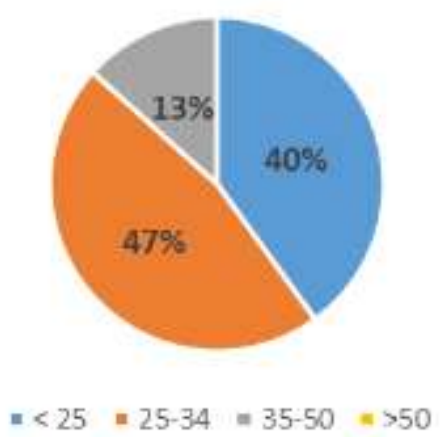

Gambar 2. Usia Peserta Sumber : Kuisioner PKM (2020), data diolah

\section{Pendidikan Peserta}

Latar belakang pendidikan dari peserta kegiatan ini paling banyak adalah SD-SMA sebanyak 87\%, Sarjana (S1-S2) sebanyak $7 \%$ dan paling sedikit sebanyak $6 \%$ dengan latar belakang pendidikan dari Sarjana Muda (D1-D4). 


\section{Pendidikan Peserta}

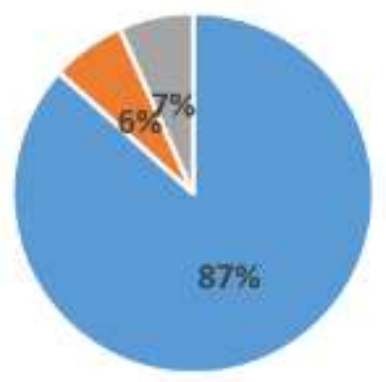

$=$ SD-SMA $=\mathrm{D} 1-\mathrm{DM}=\mathrm{S} 1-\mathrm{S} 2=\mathrm{S} 3$

Gambar 3. Pendidikan Peserta. Sumber

: Kuisioner PKM (2020), data diolah.

\section{Pekerjaan Peserta}

Dari data kuisioner didapatkan $73 \%$ berprofesi sebagai ibu rumah tangga, $20 \%$ berprofesi sebagai wiraswasta dan $7 \%$ sebagai dosen. Adapun diagram persentase dapat dilihat dibawah ini:

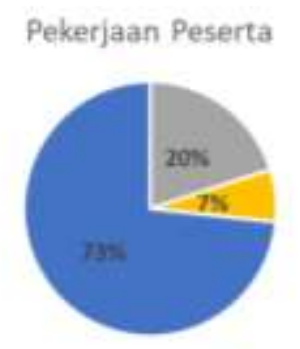

Gambar 4. Pekerjaan Peserta. Sumber :

Kuisioner PKM (2020), data diolah

\section{Ketertarikan peserta terhadap}

program

Untuk melihat feedback dari peserta, kepada peserta juga di sertakan pertanyaan mengenai pelaksanaan kegiatan. Pertanyaan terdiri dari tiga komponen yaitu bagaimana ketertarikan mereka terhadap kegiatan, ketertarikan terhadap materi dan ketertarikan terhadap narasumber atau penyaji materi.

a. Kegiatan yang dilakukan. Dengan adanya kegiatan ini menurut mereka sangat bermanfaat bagi menambah pengetahuan mereka. Dalam kondisi pandemic seperti ini dimana aktivitas banyak dilakukan dari rumah sehingga acara ini sangat membantu mereka. Dari kuisioner yang diberikan didapatkan $60 \%$ peserta mengatakan acara ini sangat menarik dan $40 \%$ mengatakan acara ini menarik, seperti ditunjukkan pada Gambar 5.

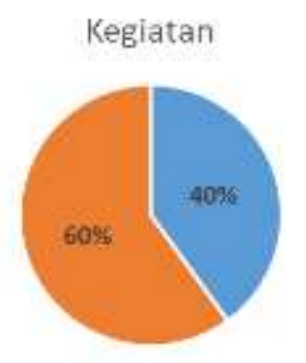

a Menatik. - Saltgat menatik

Gambar 5a. Ketertarikan peserta terhadap kegiatan. Sumber : Kuisioner (2020), data diolah 
b. Materi yang diberikan bisa membuat para peserta tertarik untuk mengikutinya. Disamping mereka membutuhkan juga informasi dan demo bagi mereka ini adalah pertama kalinya mengikuti acara secara online dan berbeda dengan cara penyuluhan yang biasa dilakukan. Dari kuisioner yang dilakukan didapatkan 53\% peserta menyatakan kegiatan ini sangat menarik sedangkan $47 \%$ peserta menyatakan kegiatan ini menarik. Sehingga sebagian besar mereka meminta agar acara ini rutin dilakukan. Adapun rinciannya dapat dilihat dari diagram pada Gambar 6.

\section{Ketertarikan Peserta terhadap Topik}

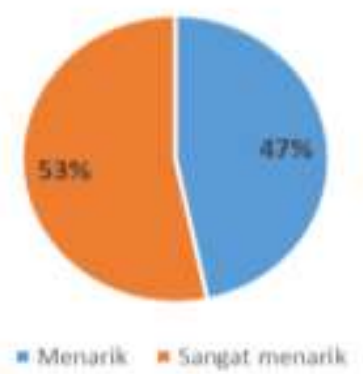

Gambar 6. Ketertarikan peserta terhadap topik. Sumber: Kuisioner (2020), data diolah

c. Penyajian Materi. Dari penyajian materi yang diberikan, dimana narasumber memberikan penjelasan yang komplit dan menarik disertai dengan demo. Meskipun dilakukan secara online, hal ini tidak menghalangi mereka untuk berdiskusi dan banyak bertanya tentang masalah laktasi. Sehingga $73 \%$ peserta mengatakan penyajian materi ini sangat menarik dan $27 \%$ mengatakan menarik seperti yang ditunjukkan pada Gambar 6.

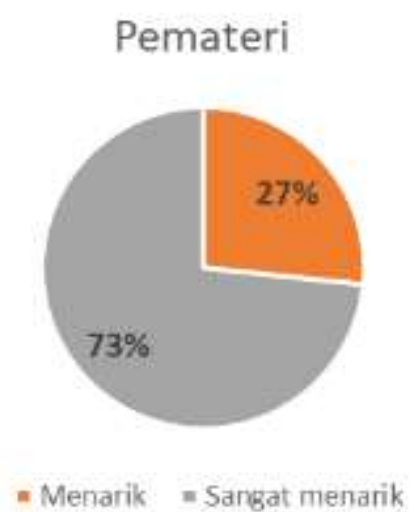

Gambar 7. Penyajian Materi. Sumber: Kuisioner (2020), data diolah

\section{Media yang digunakan}

Dari segi sarana yang digunakan pada kesempatan pengabdian kepada masyarakat kali ini dengan menggunakan Zoom maka sebagian besar mereka sangat tertarik dan sangat paham dengan materi yang diberikan. Selama pelaksanaan acara penyuluhan online semua peserta terkoneksi baik dengan acara yang diselenggarakan. Dari hasil kuisioner didapatkan bahwa $80 \%$ 
menyatakan menarik dan sisanya $20 \%$ menyatakan sangat menarik, seperti terlihat dalam diagram berikut.

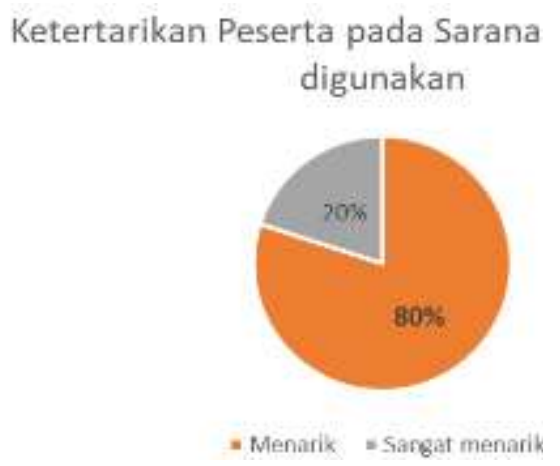

Gambar 8. Ketertarikan Peserta pada media yang digunakan. Sumber: Kuisioner (2020), data diolah

\section{Hasil Pretest dan Post test}

Untuk pretest ini ada 8 pertanyaan yang diberikan, pertanyaaan-pertanyaan tersebut dapat dikelompokkan kedalam 3 kategori yaitu pengetahuan dasar ASI, teknik pemberian ASI dan phycologis menyusui. Pertanyaan ini diberikan sebelum mereka mendapatkan penyuluhan. Rata-rata skor pretest adalah sebesar 38/100, dimana yang dapat menjawab dengan betul 4 soal dari total 8 soal sebanyak 4 orang sedangkan yang dapat menjawab 1 soal dengan betul adalah sebanyak 1 orang. Adapun tabel penghitungan pretest dapat dilihat pada Tabel 1 .
Tabel 1:

\begin{tabular}{|c|c|c|c|c|c|}
\hline \multicolumn{6}{|c|}{ PREIESI } \\
\hline & & Freguency & Percent & Vald Pertent & $\begin{array}{l}\text { Cumulative } \\
\text { Percent }\end{array}$ \\
\hline \multirow[t]{7}{*}{ Vailia } & 12.50 & 2 & 133 & 13.3 & 13.3 \\
\hline & 25.00 & 4 & 267 & 20.7 & 400 \\
\hline & 37.50 & 3 & 200 & 20.0 & 60.0 \\
\hline & 50.00 & 4 & 26.7 & 26.7 & 86.7 \\
\hline & 52.50 & 1 & 67 & 6.7 & 93.3 \\
\hline & 75.00 & 1 & 6.7 & 6.7 & 100.0 \\
\hline & Total & 15 & 1000 & 100.0 & \\
\hline
\end{tabular}

Setelah Pretest diberikan maka pseserta diberikan penyuluhan mengenai manajemen laktasi yang meliputi cara membersihkan alat yang akan digunakan, teknik pemerasan, cara penyimpanan ASI serta cara pemberian ASI yang betul kepada bayi. Diskusi berlangsung antara peserta dan pembicara menanyakan hal-hal yang bersifat teknis. Setelah itu diberikan kepada peserta post test yang terdiri atas 8 pertanyaan. Dari jawaban yang diberikan peserta maka didapat rata-rata post test sebesar $82 / 100$. Tujuh soal dari sepuluh soal dijawab dengan benar oleh delapan orang dan satu orang menjawab dengan betul semua pertanyaan. Adapun tabel penghitungan post test dapat dilihat pada Table 2 .

Tabel 2: Hasil Posttest

\begin{tabular}{|c|c|c|c|c|c|}
\hline \multicolumn{6}{|c|}{ POSITEST } \\
\hline & & Frequancy & Percant & Valid Pencent & $\begin{array}{c}\text { Cumutabive } \\
\text { Portant }\end{array}$ \\
\hline \multirow[t]{5}{*}{ Valid } & 5000 & 1 & 67 & 8.7 & 47 \\
\hline & 75,00 & 5 & 393 & $n_{3}$ & 400 \\
\hline & 9750 & 8 & 533 & 533 & 803 \\
\hline & 100.00 & $t$ & 67 & 67 & 1000 \\
\hline & Total & 15 & 1000 & 1000 & \\
\hline
\end{tabular}


Dari hasil pretest dan posttest yang kita berikan terdapat peningkatan secara statistic berdasarkan perhitungan paired t-test pada SPSS dengan $\mathrm{p}<0.05$, seperti dilihat pada Table 3 .

Tabel 3. Tabel perhitungan paired t-test

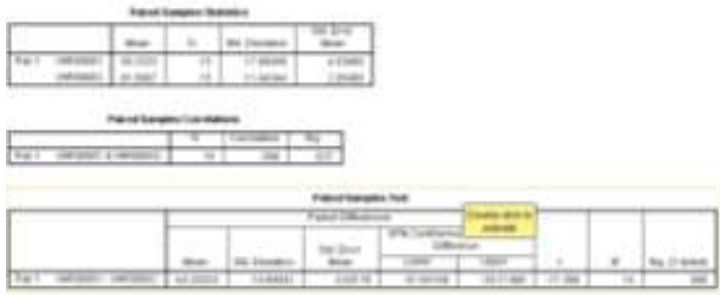

Sedangkan untuk kategori pertanyaan yang dibedakan atas 3 bagian yaitu pengetahuan dasar ASI, teknik pemberian ASI dan phycologis menyusui. Dari data pretest dan posttest didapatkan persentase jawaban yang dijawab benar oleh peserta seperti terlihat pada Tabel 4 .

Tabel 4. Persentase jawaban yang benar untuk pretest dan post test

\begin{tabular}{|l|l|l|}
\hline Group Pertanyaan & $\begin{array}{l}\text { Pre-test } \\
\text { (\% jawaban benar) }\end{array}$ & $\begin{array}{l}\text { Post - test } \\
\text { (\% Jawaban yang benar) }\end{array}$ \\
\hline Pengetahuan ASI & 45 & 91.67 \\
\hline Teknik Menyusui & 28.89 & 97.78 \\
\hline Phsycology & 40 & 93.33 \\
\hline
\end{tabular}

Sehingga dari table diatas terlihat adanya peningkatan pengetahuan yang signifikan dari pretest kepada posttest. Kegiatan Penyuluhan menggunakan metode darling ini terlihat pada gambar berikut.

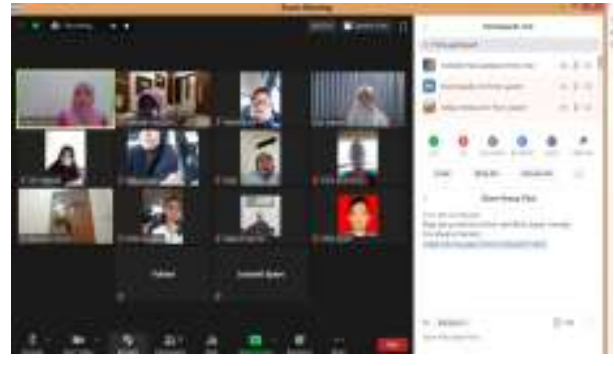

(a)

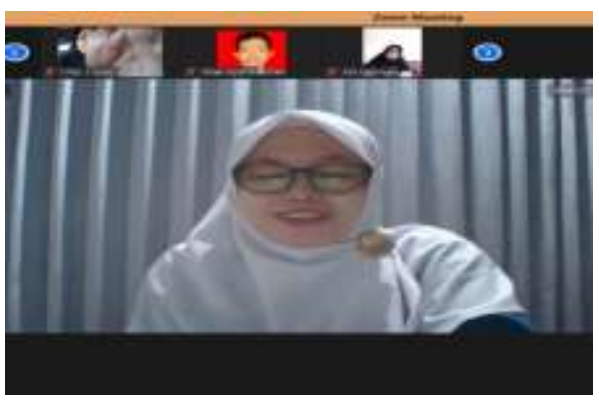

(b)

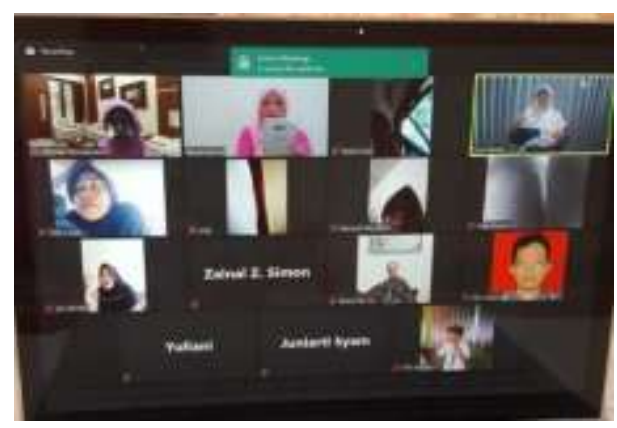

(C)

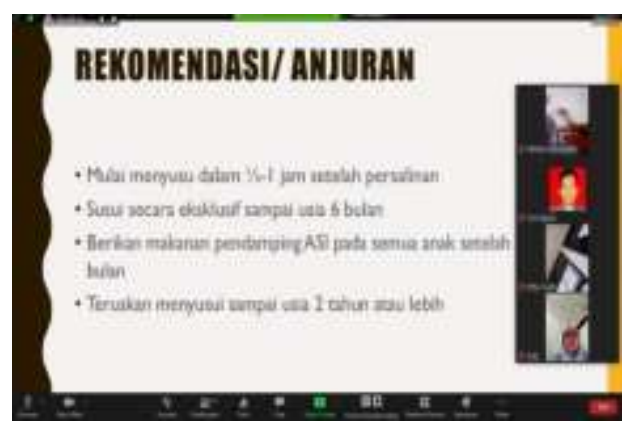

(d)

Gambar 9. Kegiatan PKM yang diselenggarakan melalui online (daring). (a) Ketua PKM membuka acara, (b). Nara sumber menyajikan materi penyuluhan. embukaan acara 
penyuluhan secara daring oleh Ketua

Kegiatan.

(c).

Narasumber

memperagakan cara menyusui anak dengan benar. (d). Beberapa anjuran yang disarankan dalam menyusui bayi yang disampaikan oleh narasumber.

\section{KESIMPULAN}

Upaya peningkatan pemahaman manajemen laktasi melalui kegiatan PKM yang diselenggaralkan di Posyandu Cempaka Merah telah memberikan manfaat bagi peserta seperti ditunjukkan oleh statistik kuisioner yang diadakan. Para peserta selain mendapatkan penjelasan yang rinci mengenai manajemen laktasi langsung dari narasumber yang ahli dibidangnya juga mendapat pengalaman tambahan berupa pemakaian teknologi untuk penuluhan secara daring.

Berdasarkan hasil uji pre dan post test yang diberikan, kegiatan PKM ini berpengaruh signifikan terhadap pengetahuan peserta tentang manajemen laktasi.

\section{DAFTAR PUSTAKA}

Ai Yeyeh, Rukiyah dkk, 2011. Asuhan Kebidanan I ( Kehamilan ). Cetakan Pertama. Jakarta: TransInfo Media;

Anhar, Wahyu. 2019. Penerapan Lampu Penerangan Jalan Umum (PJU)
Berbasis Solar Cell Terhadap Kehidupan Sosial pada Masyarakat RT. 50 Kelurahan Sepinggan Balikpapan. Jurnal Pengabdian Al-Ikhlas Universitas Islam Kalimantan Muhammad Arsyad Al Banjary, Vol 5 No 12019

Depkes RI, 2005. Managemen Laktasi. Direktorat Jenderal Bina Kesehatan Masyarakat. Jakarta.

Kissinger, 2020. PKM Fasilitasi Pelaksanaan Pendampingan Kegiatan Revegetasi Hutan Gambut. Jurnal Pengabdian Al-Ikhlas Universitas Islam Kalimantan Muhammad Arsyad Al Banjary, Vol 5 No 2020.

Maryunani, 2012. Iniasiasi menyusui dini, ASI eksklusif dan manajemen laktasi. Jakarta ,Trans Info Media.

https://www.alodokter.com/terap kan-manajemen-laktasi-gunamemastikan-kelancaran-menyusui

https://parenting.orami.co.id/ma gazine/5-faktor-penyebab-ibumenyusui-kesulitan-memberi-asieksklusif.

https://www.alodokter.com/lang kah-langkah-membersihkan-pompa-asiyang-perlu-bunda-ketahui

Perinasia. (2004). Manajemen Laktasi; Menuju Persalinan Aman dan Bayi Lahir Sehat. Edisi 2. Jakarta: Gramedia Pustaka Utama

Siregar, Arifin. 2007. Pemberian ASI Eksklusif dan Faktor-faktor yang Mempengaruhinya. Sumatra Utara: Universitas Sumatra Utara

https://www.ibupedia.com/artike 1/balita/6-cara-memberikan-asip-ke-bayi 